\title{
Work in Progress: Career Ready... or Not? A Career-Readiness Activity for Senior Chemical Engineering Students
}

\section{Dr. Daniel D. Anastasio, Rose-Hulman Institute of Technology}

Daniel Anastasio is an assistant professor at Rose-Hulman Institute of Technology. He received a B.S. and Ph.D. in Chemical Engineering from the University of Connecticut in 2009 and 2015, respectively. His primary areas of research are game-based learning in engineering courses and membrane separations for desalination and water purification.

\section{Elizabeth R. Morehouse, Rose-Hulman Institute of Technology}

Liz Morehouse is an assistant director in Career Services \& Employer Relations at Rose-Hulman Institute of Technology. She received a B.A. in Spanish and M.S. in Community Counseling from Northern Kentucky University in 2007 and 2009, respectively. She is an award-winning curriculum designer with significant experience providing leadership and career development opportunities for college students. 


\section{Work-in-Progress: Career Ready...or Not? A Career-Readiness Activity for Graduating Undergraduate Chemical Engineers}

\section{Introduction}

According to a recent poll, over $50 \%$ of student respondents think about their future career daily (Podany, 2019). Further, parents are demonstrating an increased interest in the post-graduation outcomes of their students. A recent article in the New York Times stated, "Nowadays, it's apparent to college administrators that many parents want more for their children from college than just an education. As a result, finding ways to get students to connect early with career services support has become a goal at many institutions around the country" (Hannon, 2018). Demonstrating its graduates' career readiness continues to be mission critical for institutions of higher education. But, are graduates career ready? The National Association of Colleges and Employers (NACE) surveys graduates and employers regularly to gauge their career readiness (NACE (a), 2018; NACE (b), 2018). In the recently published results, employers rated the career readiness proficiency of new graduates lower, in some cases significantly, when compared to students’ self-ratings (NACE (a), 2018). Thus, a skills gap may exist.

NACE defines career readiness as "the attainment and demonstration of requisite competencies that broadly prepare college graduates for a successful transition into the workplace” (NACE, 2017). The aforementioned definition was created in 2015 through a task force including both college and employer representatives. This definition provides a common language surrounding career readiness and allows for increased cooperation and collaboration between colleges and universities and employers. Additionally, it provides a framework that can be used by Career Services professionals when coaching students (NACE, 2017).

The career readiness competencies identified by NACE include critical thinking/problem solving, oral/written communication, teamwork/collaboration, digital technology, leadership, professionalism/work ethic, and career management (NACE, 2017). In January 2017, an eighth competency - global/intercultural fluency - was added (NACE, 2017). They are described in Table 1 on the next page. 
Table 1: NACE Career Readiness Competencies Defined.

\begin{tabular}{|c|c|c|c|c|}
\hline Competency & Definition & Employer Rating & $\begin{array}{l}\text { Employer Rating of } \\
\text { Recent Graduate } \\
\text { Proficiency }\end{array}$ & $\begin{array}{l}\text { Student Self- } \\
\text { Rating }\end{array}$ \\
\hline $\begin{array}{l}\text { Critical } \\
\text { Thinking/ } \\
\text { Problem Solving }\end{array}$ & $\begin{array}{l}\text { Exercise sound reasoning to analyze issues, } \\
\text { make decisions, and overcome problems. The } \\
\text { individual is able to obtain, interpret, and use } \\
\text { knowledge, facts, and data in this process, and } \\
\text { may demonstrate originality and inventiveness. }\end{array}$ & $\begin{array}{l}1 \\
100 \% \text { of } \\
\text { Employers Rated } \\
\text { as Essential }\end{array}$ & $\begin{array}{l}\text { 3 } \\
\text { 56.8\% of Employers } \\
\text { Rated New Graduates } \\
\text { as Proficient }\end{array}$ & $\begin{array}{l}\text { 3 } \\
\text { 79.9\% of Students } \\
\text { Rated Themselves } \\
\text { as Proficient }\end{array}$ \\
\hline $\begin{array}{l}\text { Oral/Written } \\
\text { Communication }\end{array}$ & $\begin{array}{l}\text { Articulate thoughts and ideas clearly and } \\
\text { effectively in written and oral forms to persons } \\
\text { inside and outside of the organization. The } \\
\text { individual has public speaking skills; is able to } \\
\text { express ideas to others; and can write/edit } \\
\text { memos, letters, and complex technical reports } \\
\text { clearly and effectively. }\end{array}$ & $\begin{array}{c}4 \\
\begin{array}{c}\text { 90.3\% of } \\
\text { Employers Rated } \\
\text { as Essential }\end{array}\end{array}$ & $\begin{array}{l}\text { 4 } \\
\text { 44.8\% of Employers } \\
\text { Rated New Graduates } \\
\text { as Proficient }\end{array}$ & $\begin{array}{l}\text { 4 } \\
\text { 79.4\% of Students } \\
\text { Rated Themselves } \\
\text { as Proficient }\end{array}$ \\
\hline $\begin{array}{l}\text { Teamwork/ } \\
\text { Collaboration }\end{array}$ & $\begin{array}{l}\text { Build collaborative relationships with } \\
\text { colleagues and customers representing diverse } \\
\text { cultures, races, ages, genders, religions, } \\
\text { lifestyles, and viewpoints. The individual is } \\
\text { able to work within a team structure, and can } \\
\text { negotiate and manage conflict. }\end{array}$ & $\begin{array}{c}2 \\
97.8 \% \text { of } \\
\text { Employers Rated } \\
\text { as Essential }\end{array}$ & $\begin{array}{l}1 \\
70.1 \% \text { of Employers } \\
\text { Rated New Graduates } \\
\text { as Proficient }\end{array}$ & $\begin{array}{l}\text { 2 } \\
\text { 85.1\% of Students } \\
\text { Rated Themselves } \\
\text { as Proficient }\end{array}$ \\
\hline $\begin{array}{l}\text { Digital } \\
\text { Technology }\end{array}$ & $\begin{array}{l}\text { Leverage existing digital technologies ethically } \\
\text { and efficiently to solve problems, complete } \\
\text { tasks, and accomplish goals. The individual } \\
\text { demonstrates effective adaptability to new and } \\
\text { emerging technologies. }\end{array}$ & $\begin{array}{c}5 \\
66.3 \% \text { of } \\
\text { Employers Rated } \\
\text { as Essential } \\
\end{array}$ & $\begin{array}{c}2 \\
\text { 68.8\% of Employers } \\
\text { Rated New Graduates } \\
\text { as Proficient }\end{array}$ & $\begin{array}{c}6 \\
\text { 59.9\% of Students } \\
\text { Rated Themselves } \\
\text { as Proficient }\end{array}$ \\
\hline Leadership & $\begin{array}{l}\text { Leverage the strengths of others to achieve } \\
\text { common goals, and use interpersonal skills to } \\
\text { coach and develop others. The individual is } \\
\text { able to assess and manage his/her emotions and } \\
\text { those of others; use empathetic skills to guide } \\
\text { and motivate; and organize, prioritize, and } \\
\text { delegate work. }\end{array}$ & $\begin{array}{c}6 \\
55.9 \% \text { of } \\
\text { Employers Rated } \\
\text { as Essential }\end{array}$ & $\begin{array}{c}6 \\
\text { 32.2\% of Employers } \\
\text { Rated New Graduates } \\
\text { as Proficient }\end{array}$ & $\begin{array}{c}5 \\
\text { 70.5\% of Students } \\
\text { Rated Themselves } \\
\text { as Proficient }\end{array}$ \\
\hline $\begin{array}{l}\text { Professionalism/ } \\
\text { Work Ethic }\end{array}$ & $\begin{array}{l}\text { Demonstrate personal accountability and } \\
\text { effective work habits, e.g., punctuality, working } \\
\text { productively with others, and time workload } \\
\text { management, and understand the impact of non- } \\
\text { verbal communication on professional work } \\
\text { image. The individual demonstrates integrity } \\
\text { and ethical behavior, acts responsibly with the } \\
\text { interests of the larger community in mind, and } \\
\text { is able to learn from his/her mistakes. }\end{array}$ & $\begin{array}{c}3 \\
94.5 \% \text { of } \\
\text { Employers Rated } \\
\text { as Essential }\end{array}$ & $\begin{array}{c}5 \\
44.2 \% \text { of Employers } \\
\text { Rated New Graduates } \\
\text { as Proficient }\end{array}$ & $\begin{array}{l}1 \\
\text { 89.4\% of Students } \\
\text { Rated Themselves } \\
\text { as Proficient }\end{array}$ \\
\hline $\begin{array}{l}\text { Career } \\
\text { Management }\end{array}$ & $\begin{array}{l}\text { Identify and articulate one's skills, strengths, } \\
\text { knowledge, and experiences relevant to the } \\
\text { position desired and career goals, and identify } \\
\text { areas necessary for professional growth. The } \\
\text { individual is able to navigate and explore job } \\
\text { options, understands and can take the steps } \\
\text { necessary to pursue opportunities, and } \\
\text { understands how to self-advocate for } \\
\text { opportunities in the workplace. }\end{array}$ & $\begin{array}{c}7 \\
41.3 \% \text { of } \\
\text { Employers Rated } \\
\text { as Essential }\end{array}$ & $\begin{array}{c}8 \\
\text { 26.1\% of Employers } \\
\text { Rated New Graduates } \\
\text { as Proficient }\end{array}$ & $\begin{array}{c}7 \\
40.9 \% \text { of Students } \\
\text { Rated Themselves } \\
\text { as Proficient }\end{array}$ \\
\hline $\begin{array}{l}\text { Global/ } \\
\text { Intercultural } \\
\text { Fluency }\end{array}$ & $\begin{array}{l}\text { Value, respect, and learn from diverse cultures, } \\
\text { races, ages, genders, sexual orientations, and } \\
\text { religions. The individual demonstrates } \\
\text { openness, inclusiveness, sensitivity, and the } \\
\text { ability to interact respectfully with all people } \\
\text { and understand individuals' differences. }\end{array}$ & $\begin{array}{c}8 \\
22.6 \% \text { of } \\
\text { Employers Rated } \\
\text { as Essential }\end{array}$ & $\begin{array}{c}7 \\
\text { 31.8\% of Employers } \\
\text { Rated New Graduates } \\
\text { as Proficient }\end{array}$ & $\begin{array}{l}\text { 8 } \\
\text { 34.9\% of Students } \\
\text { Rated Themselves } \\
\text { as Proficient }\end{array}$ \\
\hline
\end{tabular}


In order to introduce a group of chemical engineering students at Rose-Hulman Institute of Technology to the concept of career readiness and develop their ability to sell themselves as career ready, an interactive activity was created for a senior-level seminar course. The purpose of this paper is to describe the activity and its initial outcome. Later studies are planned to assess its effectiveness at increasing students' awareness of and ability to express the NACE competencies.

The learning outcomes established for the activity are as follows:

- Students will evaluate their performance in each competency and identify the competency in which they feel they perform strongest.

- Students will define each competency in their own words.

- Students will list examples of each competency in action.

- Students will set a minimum of three goals to improve their performance in select competencies.

The activity was later replicated in two sophomore-level courses at Rose-Hulman for the following majors: Mathematics and Biochemistry/Chemistry.

\section{Summary of Activity}

As part of a pre-class activity, students were provided basic definitions for the NACE Career Readiness Competencies. Students were then asked to complete a short online survey where they rated their confidence in their ability to express each career competency on a Likert scale from 1 (the least confident) to 8 (the most confident). After this initial ranking, students were asked to think of a specific way they have expressed each competency during their time in college. Finally, students were asked to select the competency they felt most confident expressing and the competency they felt least confident expressing. Students were encouraged to write these two competencies in their notes and bring them to class for the activity.

The in-class portion of the activity requires eight pieces of flipchart paper that can be hung on the walls or on easels and markers. After a brief introduction to NACE and the competencies by the course instructor and a representative from Career Services, students were asked to break into groups based on the competency they identified as their strongest. If no student identified as the strongest for one of the competencies, students who identified the competency as either their second or third strongest were asked to form a group to assure that each competency was represented in the activity. Each group was then tasked with defining the competency in their own words and creating a list of activities or habits that exemplify the competency, writing their results on the flipchart paper. For this task, the students were given 10-20 minutes. Instructors observed each group during this time.

After this portion of the activity, each group shared their definitions and examples with the rest of the class. While facilitating the discussion, the instructors also could share their observations about the way the groups interacted thus further illustrating the competency. Some observations that may arise for some of the groups are summarized in Table 2. 
Table 2: Possible Observations for Break-Out Group Interactions

\begin{tabular}{|c|c|}
\hline Competency & Possible Observation \\
\hline Critical Thinking/Problem Solving & $\begin{array}{l}\text { - Will likely spend the most time thinking or brainstorming before committing } \\
\text { thoughts to paper }\end{array}$ \\
\hline Oral/Written Communication & $\begin{array}{ll}\text { - } & \text { Likely to stand in a circle to communicate } \\
\text { - } & \text { Easiest to read visual aid }\end{array}$ \\
\hline Teamwork/Collaboration & $\begin{array}{l}\text { - Will give each member of the group the ability to share thoughts } \\
\text { - } \quad \text { May divide tasks among group members }\end{array}$ \\
\hline Digital Technology & $\begin{array}{l}\text { - } \quad \text { May be quietest or smallest group } \\
\text { Although students are digital natives, they may focus only on expertise with } \\
\text { technology relevant to discipline }\end{array}$ \\
\hline Leadership & $\begin{array}{ll}\text { - } & \text { Will demonstrate efficiency by finishing first } \\
\text { - } & \text { Will demonstrate some characteristics of both teamwork and communication } \\
\text { - } & \text { Will volunteer to present first }\end{array}$ \\
\hline Professionalism/Work Ethic & $\begin{array}{ll}\text { - } & \text { Will work efficiently at the task at hand } \\
\text { - } & \text { Will focus discussion on topic }\end{array}$ \\
\hline Career Management & $\begin{array}{l}\text { - } \quad \text { Students will have the most questions here; competency may be ambiguous } \\
\text { - } \quad \text { Not likely to be chosen as most comfortable skill }\end{array}$ \\
\hline Global/Intercultural Fluency & $\begin{array}{ll}\text { - } & \text { Students with international experience may choose this first } \\
\text { - } & \text { Students may be from a diverse set of backgrounds }\end{array}$ \\
\hline
\end{tabular}

Once all student teams had the opportunity to report their results, students were encouraged to read each flipchart paper and focus on competencies for which they had perceived weakness. The in-class portion of the activity ended with students encouraged to set specific, measurable, achievable, relevant, and time-bound (SMART) goals related to improving areas of weakness and ultimately finding either employment or a position in a graduate program.

With the activity complete, students were asked to take an online post-survey. This survey began similarly to the pre-class survey, asking students to rank their confidence in the different competencies, while also asking students to list their SMART goals and assessing whether students felt their understanding of career readiness improved as a result of the activity. Overall, the activity and post-activity reflection takes approximately 40-50 minutes to complete.

\section{Initial Implementation and Next Steps}

This activity was completed with a class of 67 chemical engineering seniors in the Fall 2018 academic term. During the activity, students seemed engaged with their groups, and each group completed the tasks set before them successfully. The pre-class survey was completed by 66 students, while the post-class survey was completed by all 67 students. The averaged results of student self-evaluation of confidence in each area on an eight-point Likert scale (where 1 is least confident and 8 is most confident). In the initial run of the activity, data was collected predominantly to assess if students were appropriately engaging with and reflecting on the competencies in order to improve future implementations of the activity.

While this survey represented only one class's response to the first iteration of this activity, a few trends emerged. On both the pre- and post-survey, students stated they felt most confident in critical thinking, teamwork, and professionalism. The average student response in these categories were all above 6 on the 8-point scale. This outcome was somewhat anticipated, as students in engineering disciplines tend to experience opportunities to practice critical thinking, teamwork, and maintaining a strong work ethic in most of their courses. On both surveys, 
students indicated the least confidence in career management, digital technology, and global/intercultural fluency, with the average student response for career management being slightly less than 5 on the 8-point scale. These three competencies are ones that may either be new to students or involve actively seeking opportunities beyond the standard chemical engineering curriculum.

Changes in student confidence before and after the activity does not appear to be of statistical significance, although comments on the post-survey indicated that some students gained a better understanding of some of the competencies. Several students indicated they had a better understanding of the career management competency after completing the activity. Of the 67 students who took the post-survey, 59 expressed on the post-survey that they agreed, to some extent, with the statement "My confidence in my career readiness has increased as a result of this activity.” These results and student feedback indicated the activity is worthwhile at exposing students to the career readiness competencies, while also having room for improvements.

Based on student written feedback, some students were able to make connections to direct actions they can take to appeal to employers, while others still needed more guidance. Others indicated further confusion but appreciated the opportunity to set goals. In future implementations, perhaps a stronger focus on examples with the purpose of adding to a resume or developing answers to interview questions may be emphasized as part of the activity or as a follow-up activity.

In subsequent implementation opportunities, the instructor identified students appreciated the opportunity to forward plan. Thus, completing the activity as a sophomore may be more valuable than introducing the concept to seniors. This would also allow for additional focus to be placed on how to actualize the information gained through follow-up activities focused on resume and interview skills development.

\section{References}

Hannon, K. (2018, November 2). More Colleges Are Playing the Long Game. The New York Times. Retrieved January 21, 2019, from https://www.nytimes.com/2018/11/02/education/learning/colleges-universities-careerservices.html

National Association of Colleges and Employers (a). (2018, February 18). Are College Graduates “Career Ready?” Retrieved January 21, 2019, from http://www.naceweb.org/career-readiness/competencies/are-college-graduates-careerready/

National Association of Colleges and Employers. (2017). Career Readiness for the New College Graduate: A Definition and Competencies. Retrieved from http://www.naceweb.org/uploadedfiles/pages/knowledge/articles/career-readiness-factsheet.pdf 
National Association of Colleges and Employers (b). (2018, November). Job Outlook 2019. Retrieved January 21, 2019, from http://www.naceweb.org/mynace/job-outlook/

Podany, J. (2019, January 2). Five Career Services Trends Every University Should Embrace in 2019. Retrieved January 21, 2019, from https://www.careerleadershipcollective.com/single-post/2019/01/02/5-Career-ServicesTrends-Every-University-Should-Embrace-in-2019 